\title{
【寄 畫】
}

\section{ミセットサイクロンについての一実験}

上网豊(1)

\section{An Experiment on Midget Cyclone Separator}

\author{
by Yutaka UEokA
}

\section{1. 緒言}

直径数 $\mathrm{cm}$ 程度の超小型サイクロン分離器を仮りに ミゼットサイクロンと呼ぶことにする。サイクロンの 一般的傾向として直径の小なるるの添ど捕集効率のよ いことから類推して，この種のサイクロンが高性能を もつことは從来より予測され, 村上教授 ${ }^{(2)}$ は最近一部 結果を発表され，また Linden (3) は気流中に含まれた

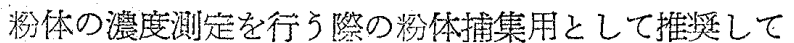
いる。しかし現在まできわめて凟料に泛しいので，実

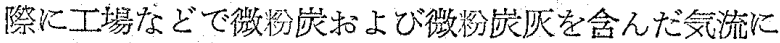
ついて濃度の测定を行了㻛合ぞの程度の儲賴性を持っ て便用できるが確かめる目的で，内径 $20 \mathrm{~mm}$ のミ ゼットサイクロンを試作し，これを用いて上記 2 種の 粉体について簡箸な笑験を行ってみたのでその結果を 報告する。

\section{2. 实験堎置および方法}

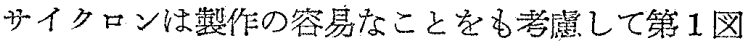
のような形状寸法のものと

した. 本体は博鍋棒材より 旋盤加工により仕上げ，翰 送管は内径 $\mathrm{mm}$ ，肉厚 1 $\mathrm{mm}$ の銅管を第いたが，唡 都とも内面は大念にみがか

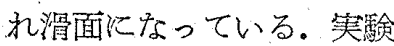

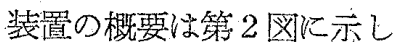
たと物りでめる。專ら笻気

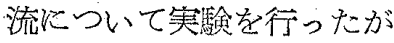
風量測定用の管内オリフィ スはあらかじめ絶対法に上 る浮タンク式の流量測定装 置で精密に検定した。供試 粉体はやや䊀庤のあらいも のまで用いたが，粒展の分 級にはタイラー標準ふるい を使用し十分振とうを行っ

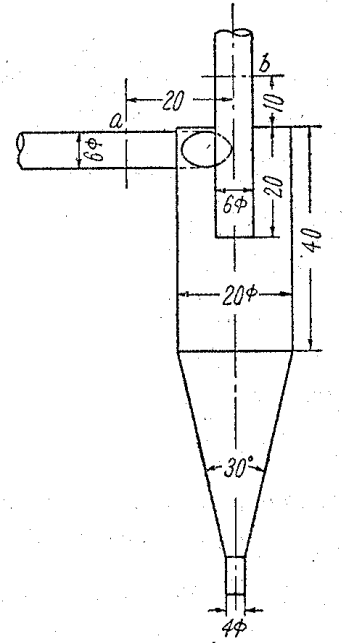

第1図、ミゼットサイク ロン形状寸法図 $(a, b$ は 王力測定孔の位置) た。試料は 1 回 $10 \mathrm{~g}$ つうる用い，試料供給ホッパは 絶えず機械的な微小振動を与兄ることにより一様に供 給させるようにした。試料混入位置からかイクロンま

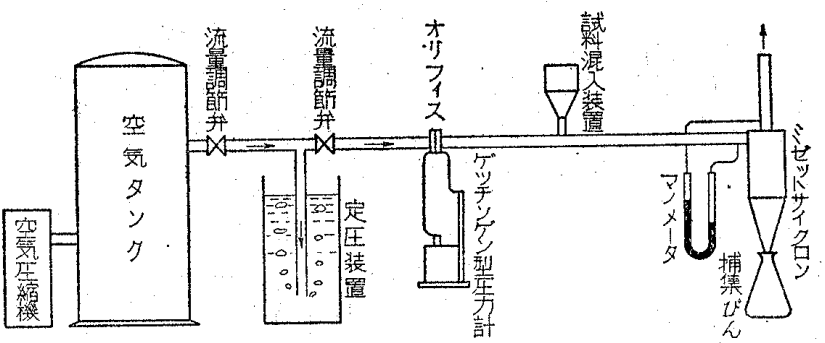

第2 2 図，笑験装置概要図

での管長は $1.2 m$ である。供給試料および捕集試料 は天榣により科量し, 容器々の他へ附着した微量の汾 末までも十分の注意を払って敢报った。測定は同一実 驗を 3 回づつ綝返しその平均値をとった。な和実験は 冬期们行った日ので空気の温度 $4 \sim 10^{\circ} \mathrm{C}$, 湿度 65 70\% であった。

\section{3. 実験結果および考察}

筙1表 試料汾体

\begin{tabular}{|c|c|c|}
\hline 種 類 & $(0,0)$ & \\
\hline 貵比重 & & 18 \\
\hline & 4 圆 & 第 5 \\
\hline & \multicolumn{2}{|l|}{ 記 } \\
\hline $100 \sim 150$ & - & $-\cdots$ \\
\hline $150 \sim 200$ & $-\square-$ & $-\cdots$ \\
\hline 0 & $-\Delta-$ & $--\Delta$ \\
\hline $0 \sim 300$ & $\rightarrow$ & $-\cdots$ \\
\hline & & \\
\hline
\end{tabular}

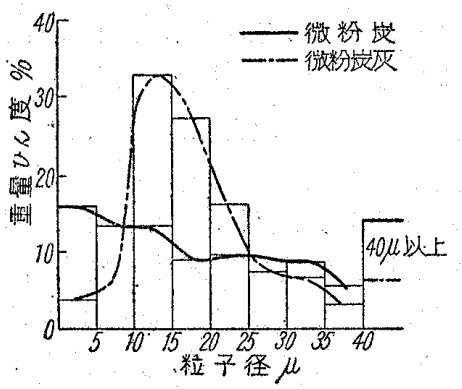

第 3 図 300 xシュ通過試 料の粒度分布
ミルで枌砕され た微粉孷拉よびコ ットレルで捕集さ れた微吩炭灰を試 料に用い，第・1 表 に示した粒度につ いて実験を行った が，300メシュ通 過の試料について 水渡, 荒川式の自 動粒度测定器比 り測定した粒度分 布は第 3 図の上5 であった。

試料粉体の混命 濃度は各実験とも 空気との重量比で 6\%を基準にした。 特の和のの試料に ついて流入平均風 速を $3 \mathrm{~m} / \mathrm{s}$ 放 30 $\mathrm{m} / \mathrm{s}$ の間汇颃いて 種々湾えて行。 
た捕集効率の測定結果はそれぞれ第 4 図，第 5 図であ る・これによるとサイクロンの一般的傾问として粒度 の小になるほど分離效率は次第に悪くなることを示し ているが，乙かし全般的に見ると非常に良好な效率と 言える. 特に流入風速 $3 \mathrm{~m} / \mathrm{s}$ の低速で，な抹相当よ い效率を維持していることは注目に值する。そしてか えって $20 \mathrm{~m} / \mathrm{s}$ の風速の附近で效率の低下を示し，そ の後やや向上していることは程度の差はあるが第 4 図 第 5 目共通である.この低速に拉いて效率の高い理

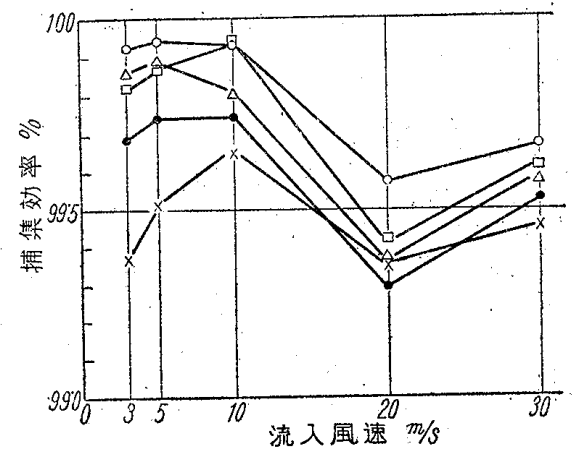

第 4 図 微吩宸についての捕集效率

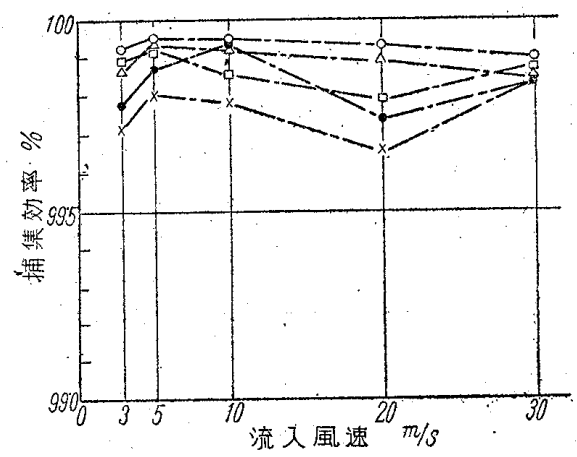

第 5 図 微粉炭灰についての捕集効率

由をして考党られることは，（a）流入管路が細く， したがって低速に和いては管路内の流れのレイノルズ 数を計算してみても完全に曆流の範囲にあることにな り，供給粉体の解離が乱流のように十分に行われず， 結局粒度が大なる場合と同様な現象を呈する。（） 後述するサイクロン内での压力嘪失の測定結果からも 推察されるように，流入風速が小であるときはサイク ロン内部の流れも尿流的で乱れが少いと考えられる。 このためある程度流入風速が大になると弪体に作用す る薏心力は当然大になるにもかかわらず，流れが十分 乱れるために粉体は乱れのうずに巻きこまれて出口 管に向う傾向が強くなり，効率は増加せず，かえって 若千減少する結果を示すことなどである.そして（a） の理由が利いているとして多少割引きして考えても比 較的低速でも効率はな特相当良好であると見なしてよ いようであって，いずれにしてる既に十分乱れた流れ の状態で用いられる普通のサイクロンに比して面白い 現象である，また第 4 図と第 5 図を比較すると，第 5 図の微粉㞸灰についての効率が優秀であることがわか
るが，これは両者の比重の恙の他にその形状の差異る 原因しているのであろう，顕微鏡でしらべてみると不

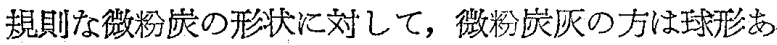
るいはだ円㓞であり，ふるいで選別した瑝命同一粒 度では比表面積は当然前者が大になるはずで，このこ

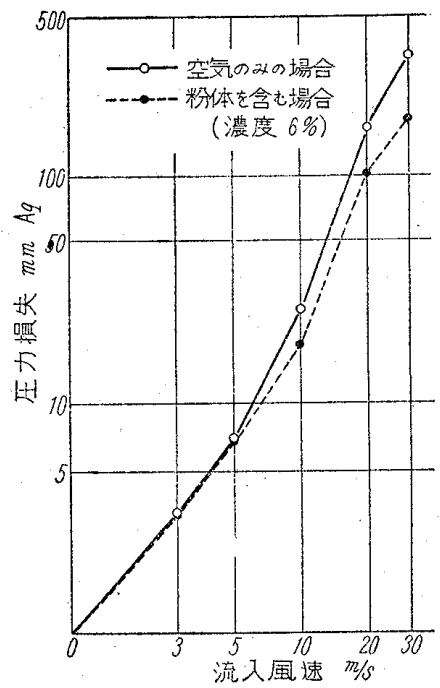

第 6 図 流入風速と压力 損失の関俬
とはもちろん，沈 降速或に影馏を及 将するのと思われ る.

次第 6 図は第 1 図に示された位 置の測定孔に和い て測ったサイクロ ン内部での压力損 失の值である、流 入風速の小なる間 はほほ流入速度に 比例する傾间にあ るが，漸次変化し 高速では速度の二 乘に比例するよう. になる。今この压 力損失を $\Delta p \mathrm{~kg} / \mathrm{m}^{2}$ 流入空气比重量を $\gamma \mathrm{kg} / \mathrm{m}^{3}$, 流入風速 $v \mathrm{~m} / \mathrm{s}$, 重力 の加速度 $g \mathrm{~m} / \mathrm{s}^{2}$ として， $\zeta=\Delta p /\left(\frac{\gamma v^{2}}{2 g}\right)$ で定義され る圧力損失係数ら学求めてみると空気流のみの場合の 值は第 2 袁のようになる。その傾向は面白いことに捕

第 2 表 流大風速と圧力損失俰数の関係

\begin{tabular}{c|c|c|c|c|c}
\hline 流入風速 $v \mathrm{~m} / \mathrm{s}$ & 3 & 5 & 10 & 20 & 30 \\
\hline 压力損失係数 $\zeta$ & $6^{* 10}$ & $4^{\circ} 52$ & $4^{\circ} 65$ & $5 \cdot 89$ & $5 \cdot 92$ \\
\hline
\end{tabular}

集効率の曲線とちょ5ど逆であり，同形の大型サイク ロンに比べる、とやや小さな值である。交第 6 図より 汾体の含有汇上って压力損失は特に高速に和いて相当 減少することがわかるが，その減少割合は大型サイク ロンの場合と大して差異はないようである. Linden ${ }^{(3)}$ はその論文の中でサイクロン内での圧力損失と流入風 速の関係をあらかじめ検定して特いて，使用時には特 別に風量測定用のオリフィスを設けずに，サイクロン の圧力損失を測定して逆に風速を推定する方法をのべ ている、しかし上述のように，一般サイクロンと同様 に気流中の吩体含有量汒上る圧力損失の変化が無視で きない程度のものであることがわかったので, Linden の提菜はよほど含有量の微量な場合か，あるいはあら かじめ濃度の俚力損失に更ぼす影響がわかっている場 合などでない限り適用できないのではないかと思われ る.次にサイクロン内部での流れの模様については村 上教授(2)が詳しく測定して和られるが，筆者は流入気 流に水滴を霧状にして混じ，暫時放置した後サイク口 ン内面に生ずる鮮明なさびの曲線により壁面に沿っ 
ての流線を求めてみ

た.第 7 园はその一例 であって円とつ部では 1.5 回転であるが円す い部では 3 回転してお りまた内部円とう部 でのら旋角は相当大き く村上教授の場合の測 定値とほぼ一致してい る.

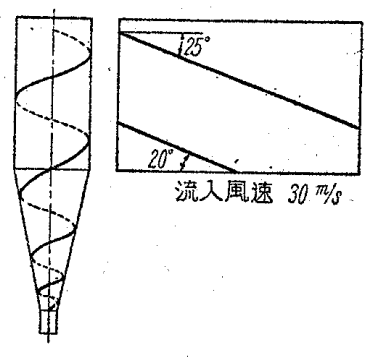

第7図 壁面に沿っての ら揟流の流線

\section{4. 結 論}

特定の烙体試料を用いたきわめて狭い範囲の実験で はあるが試作したミゼットサイクロンの捕集効率は予 想通り優秀であることを確認することができた。した がって緒言に揖いてのべた目的に十分応用できる以外 に特殊サイクロンとして各方面に用途が開けるものと
期待される。単独の場合の妈理流量はるるろんわうかか であるが，マルチクロン的な応用も考兄られ，また低 い流入風速では巣に速度頭のみでなく，压力損失係数 も小になることと相まって圧力損失はきわめてわつが で済み，しかもかなり高い捕集効率を維持できること は動力面より見ても将来発展の示唆を含んでいるよう に思方る。しかし々の性質については一般のサイク ロンと同樣な傾向もあるが，小型であるための独自の 現象も起っているようであって，解明すべき興味潹い 問題も多々包蔵されている. 本研究に当り御指導を賜 わった東京工大板谷松樹教授並びに種る便宜を与えら れた宇部鉄工所に対し厚く感謝する。

注: -

(1) 正員, 山口大学工学部.

(2) 村上, 福永: 機械学会論交集, 18 巻 73 费, 56 ページ (昭 27)。

(3) Linden, Engg., 1949-2-18, p. 165.

$620.193 .15: 621.224-253.5$

\title{
砂粒混在の流水による わん形水受 の摩耗について（その1 $)^{(1)}$
}

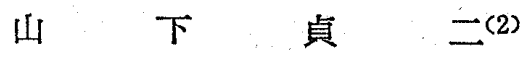

\author{
On the Abrasion of the Pelton Wheel's Backet \\ to the Fluid with Sand Particles (No. 1) \\ by Sadaji Yamashita
}

\begin{abstract}
As there were not any study of the abrasion between the rigid body and the rigid body in the current liquid, the present author studied on the abrasion of metals to the fluid with sand grains as the study in this case.

In this report, he deseribes his study on the fundamental mechanism of abrasion of the pelton wheel's backets to the fluid with sand particles, and reports on the relation between the radius of curvature of the semicircular section of the backet, the static pressure. of the flow water and the wear.
\end{abstract}

\section{1. 緒言}

交献(3)によると，摩耗に関しては幾多の実験研究が なされているが，それの機構に関しては明確でない点 が多い，これる比較的に研究されている固体間の摩耗 についてであって，本研究のごとき場合すなわち微小 固体が流体中に混入し，この流体が固体と接触する場 合のごときはきわめてすくない(4)，乙かるに水車の羽 根, 案内羽根, 水受, ノズル, 污水ポンプ扣よびパイ プ，ある種の反応鉒，液体サイクロン，サンドブラス ト执び液体ホーニングなどのごとく，現実に和いて は，これらの消耗および利用は影響する所が大きい。
ここに特いて，この場合の摩耗として「砂粒混在の 流水に対する金属材料の摩耗」を取り上げ，その摩耗 機構を明らかにする目的で実験的究眀を行い，すでに 発表した箠者の研究(5)に特いて，この場合の摩耗機構 について述べた所を総括すると，

（1）この場合の摩耗機構は機械的破壊によるもの であり(6)，固体一固体間の乾燥摩耗と同様な機構によ るもので,すなわち初摩耗があり摩耗減量方割合に大 で, 後に定常摩耗となり摩耕減量は小となる。しかし て表面は冷間加工されたるののごとくかたさも大と なりまた摩耗面の最上層は䋐維状買を是し，下層と の中間層の金属粒子は微粒化している(7). 